\title{
STUDI IDENTIFIKASI PENGEMBANGAN KAWASAN KANTOR BUPATI DI KABUPATEN KOLAKA TIMUR
}

\author{
Baso Asnang ${ }^{1}$ \\ ${ }^{1}$ Prodi Arsitektur, Fakultas Teknik, Universitas Muslim Indonesia
}

\begin{abstract}
Abstrak
Meningkatnya pertumbuhan penduduk di Kabupaten Kolaka maka pada tanggal 11 januari 2013, Kabupaten Kolaka memekarkan Kabupaten baru yaitu Kabupaten Kolaka Timur. Sarana perkantoran pemerintahan kabupaten Kolaka Timur merupakan wadah untuk melaksanakan kegiatan pemerintahan daerah setempat dalam melaksanakan tugas pelayanan kepada masyarakat dan melayani kepentingan umum di wilayah Kabupaten. Saat ini, rata - rata peningkatan jumlah pegawai terus meningkat terjadi peningkatan sebesar $0.074 \%$ pada tahun 2015 (Bagian Organisasi dan Tata Laksana sekertariat Daerah, 2015). Dengan presentase jumlah pegawai yang terus meningkat maka salah satu sarana perkantoran yang dibutuhkan oleh suatu kabupaten baru yaitu kantor bupati. Secara fisik, penataan ruangan dan tampilan bangunan kantor bupati Kolaka Timur terlihat sederhana yang dibangun dengan luas $24 \mathrm{~m} \mathrm{X} 18 \mathrm{~m}$ persegi dan tidak terdapat fasilitas - fasilitas penunjang lainnya. Berdasarkan latar belakang diatas, dapat dirumuskan dua masalah yang timbul yakni Bagaimana konsep perencanaan kantor bupati Kolaka Timur yang layak sebagai tempat yang dapat menampung kegiatan pemerintahan agar lebih efektif dan efisien dan Bagaimana mewujudkan bentuk penampilan, tata ruang dan struktur bangunan yang dilengkapi dengan fasilitas - fasilitas penunjang lainnya yang sesuai dengan fungsi bangunan kantor Bupati di Kolaka Timur.
\end{abstract}

Kata kunci: Identifikasi, Kawasan, Kantor Bupati

\begin{abstract}
Increasing population growth in Kolaka District then on January 11, 2013, Kolaka Regency splits a new regency of East Kolaka District. The administrative office of the district administration of East Kolaka is a place to carry out the activities of local government in carrying out the duty of service to society and serve public interest in Regency area. Currently, the average increase in the number of employees continues to increase there is an increase of 0.074\% in 2015 (Section Organization and Administration sekertariat Daerah, 2015). With the percentage of the number of employees who continue to increase then one of the office facilities needed by a new district is the office of the regent. Physically, the arrangement of the room and the appearance of the office building of the regent of Kolaka Timur looks simple built with an area of $24 \mathrm{mX} 18 \mathrm{sq}$ m and there are no other supporting facilities. Based on the above background, can be formulated two problems that arise that is how the concept of office planning regent of East Kolaka decent as a place that can accommodate government activities to be more effective and efficient and How to realize the form of appearance, layout and building structures equipped with facilities - facilities other supporters in accordance with the function of the Regent's office building in East Kolaka.
\end{abstract}

Keywords: Identification, Regions, Bupati's Office

\section{PENDAHUUAN}

Provinsi Sulawesi Tenggara terletak di Tenggara Pulau Sulawesi adalah sebuah provinsi di Indonesia yang beribukotakan Kendari dan memiliki 12 kabupaten, yang salah satunya adalah Kabupaten Kolaka. Jumlah penduduk Kabupaten Kolaka merupakan yang terpadat dari 12 kabupaten di Sulawesi Tenggara. Kabupaten Kolaka mempunyai luas wilayah $\pm 6.18,38 \mathrm{~km}$ dengan jumlah penduduk pada tahun 2012 berjumlah +368.322 jiwa terdiri atas 20 (dua puluh) kecamatan dan 213 (dua ratus tiga belas) desa/kelurahan. Meningkatnya pertumbuhan penduduk di Kabupaten Kolaka maka pada tanggal 11 januari 2013, Kabupaten Kolaka memekarkan Kabupaten baru yaitu Kabupaten Kolaka Timur.

Terbentuknya Kabupaten Kolaka Timur upaya pelayanan pemerintah terhadap masyarakat bisa lebih efisien apabila sarana pelayanan publik untuk menjalankan roda pemerintahan telah terpenuhi. Selain itu, dengan adanya pelayanan publik segala urusan tata pemerintahan dapat berjalan lancar dan dapat mempercepat terwujudnya kesejahteraan masyarakat.

Langkah awal dalam pembangunan wilayah Kabupaten Kolaka Timur, Kolaka Timur membutuhkan sarana untuk menyelenggaraan kegiatan pemerintahan. Sarana perkantoran 
pemerintahan kabupaten Kolaka Timur merupakan wadah untuk melaksanakan kegiatan pemerintahan daerah setempat dalam melaksanakan tugas pelayanan kepada masyarakat dan melayani kepentingan umum diwilayah Kabupaten. Pembangunan dan peningkatan sarana perkantoran pemerintahan Kabupaten Kolaka Timur merupakan salah satu wujud untuk melaksanakan fungsi pemerintahan yang berkualitas. Saat ini, rata - rata peningkatan jumlah pegawai terus meningkat terjadi peningkatan sebesar $0.074 \%$ pada tahun 2015 (Bagian Organisasi dan Tata Laksana sekertariat Daerah, 2015).

Dengan presentase jumlah pegawai yang terus meningkat maka salah satu sarana perkantoran yang dibutuhkan oleh suatu kabupaten baru yaitu kantor bupati.

Secara fisik, penataan ruangan dan tampilan bangunan kantor bupati Kolaka Timur terlihat sederhana yang dibangun dengan luas 24 m X 18 m persegi dan tidak terdapat fasilitas - fasilitas penunjang lainnya. Penataan tata luar luar kantor bupati Kolaka Timur tidak diperhitungkan dan direncanakaan membuat penataan parkir menjadi tidak teratur sehingga para pegawai parkir sembarangan tempat. Selain penataan parkir, lapangan upacara juga tidak direncanakan tidak terdapat mimbar upacara hanya memanfaatkan Loby sebagai mimbar upacara. Selain itu, terdapat juga permasalahan dari segi lokasi yang tidak mendukung fungsi bangunan, dimana terletak pada kawasan pelayanan umum. Berdasarkan hal tersebut maka tidak dapat dilakukan pengembangan terhadap fisik bangunan pada lahan yang sama.

Berdasarkan uraian diatas, Kolaka Timur membutuhkan kantor bupati yang dapat menampung seluruh aktivitas pegawai sekertariat daerah kabupaten yang layak digunakan sebagai kantor pemeritahan.

Dengan latar belakang tersebutlah maka peneliti terdorong untuk melakukan penelitian tentang masalah tersebut diatas.

\section{ISI PENELITIAN}

\subsection{Pendekatan Makro}

\subsection{Penentuan Lokasi}

Lokasi merupakan salah satu hal yang penting dalam perencanaan sebuah bangunan karena lokasi yang strategis bisa menjadi pertimbangan bagi para pengunjung untuk memanfaatkan keberadaan Kantor Bupati. Sehingga lokasi yang dipilih untuk bangunan kantor bupati selain menjadi pusat dari pemerintahan, bisa menjadi ikon sebuah daerah.

Dalam menentukan lokasi perencanaan harus disesuaikan dengan rencana sistem perkotaan. Adapun yang menjadi pertimbangan dalam pemilihan lokasi adalah

a. Pemilihan lokasi strategis untuk perletakan bangunan Kantor Bupati Kabupaten Kolaka Timur. b. Lokasi harus berada pada kawasan pemerintahan dengan jalur infrastruktur dan tranportasi yang mendukung serta menunjang.

c. Lokasi yang terpilih nantinya harus terdapat keseimbangan antara bangunan dan lingkungan sekitarnya sehingga Kantor Bupati Kolaka Timur bisa menjadi salah satu tanda ikon Kabupaten Kolaka Timur.

d. Lokasi merupakan lahan pemerintah dan tidak termasuk dalam daerah padat, hal ini dimaksudkan untuk prediksi untuk tahun akan datang pengembangan Kabupaten Kolaka Timur khusunya Perkantoran, pemukiman, dan industri.

\subsubsection{Penentuan Site}

Penentuan site merupakan salah satu aspek penting dalam sebuah perencanaan bangunan Kantor Bupati yang menghubungkan kondisi lahan dengan keadaan di sekitar lahan. Dalam menentukan site yang baik untuk bangunan Kantor bupati ada beberapa hal yang menjadi dasar pertimbangan dan kriteria yaitu :

a. Faktor representatif, dimana kondisi site dapat mendukung perletakan bangunan.

b. Potensi site yang tersedia dapat menunjang segala pengadaan dan aktivitas.

c. Kondisi daya dukung tanah dan lingkungan mendukung

d. Sirkulasi lalu lintas lancar dari lokasi ke jalur lalu lintas.

e. Kondisi site mendukung penampilan bangunan, mudah dalam pencarian alamat lokasi.

f. Dapat menunjang pelaksanaan pengembangan lingkungan.

\subsubsection{Pengolahan tapak/site}

Pengolahan Tapak merupakan aspek yang memuat informasi tentang hal-hal yang diperlukan dan berkaitan dengan tapak yang ada untuk kegiatan pra-perancangan dengan memperhatikan pertimbangan dan kriteria sebagai berikut :

a. Existing condition tapak

b. Kondisi fisik tapak

c. Sirkulasi

d. Kebisingan

e. Orientasi matahari

f. Sistem utilitas

g. Curah Hujan

h. Orientasi terhadap angin

i. Analisa lingkungan sekitar

Berdasarkan pertimbangan dan kriteria di atas maka pendekatan tapak (analisa tapak) menghasilkan gambaran tentang kondisi tapak sebagai berikut :

a. Existing condition tapak, yaitu gambaran mengenai situasi sekitar tapak. 
1) Sebelah barat berdekatan dengan pepoonan pinus

2) Sebelah utara puncak bukit berbatasan dengan pohon pinus.

3) Sebelah timur berbatasan dengan pintu masuk perkantoran.

4) Sebelah selatan pemandangan ke bawah dari puncak bukit

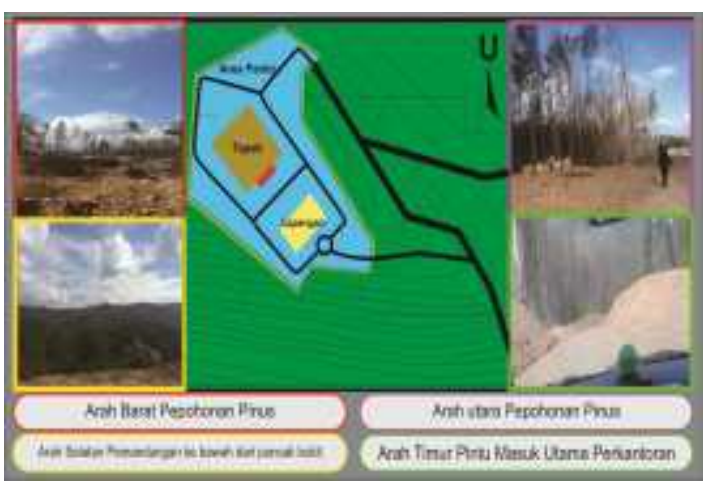

Gambar 1. Existing Condition Tapak

Sumber : Badan perencana pembangunan daearah dan foto pribadi 2015

b. Kondisi fisik tapak

1) Luasan tapak

Luasan tapak yang mencukupi untuk perencanaan Kantor Bupati. Adapun lingkungan mendukung karena berada dikawasan Perkantoran.

2) Topografi

Kondisi topografinya berada di kawasan yang berbukit namun kondisi tapak untuk perletakan bangunan relatif datar.

\subsubsection{Sirkulasi}

Agar tidak saling mengganggu dalam kegiatan rutinnya, maka pada prinsipnya sirkulasi dan pencapaian dalam Bangunan Kantor bupati di Kolaka timur perlu dipisahkan antara sirkulasi dan pencapaian :

1) Berdasarkan rencana dan besarnya jalan yang ada atau yang akan dibuat dan diperkirakan datangnya pengunjung terbanyak ditinjau dari sistem sirkulasi dan kemudahan pencapaian.

2) Untuk mempermudah sirkulasi maka perlu dipisahkan antara jalan masuk ke tapak dengan jalan keluar dari tapak (khusus untuk kendaraan)

3) Sirkulasi menuju kantor bupati di akses dari arah timur menuju pintu gebang kantor bupati (arah barat). Sirkulasi jalan masuk dan jalan keluar dari kantor bupati terdapat dua arah jalan sehingga memudahkan para pengguna bangunan mengakses jalan masuk dan keluar dari kantor bupati.

4) Intensitas kendaraan yang lewat tergolong sedang karana sirkulasi jalan masuk dan keluar dari kantor bupati hanya di peruntukkan oleh pengguna bangunan dan pengunjung

5) Ada tiga pintu masuk kedalam kantor bupati. Namun, pintu masuk utama berada di sisi timur. Pertimbangan desain dengan tiga pintu adalah demi kemudahan pencapaian bagi para pegawai dan pengunjung. Pintu masuk utama dari sisi timur merupakan akses utama bagi para pimpinan kantor bupati

6) Antara jalan masuk dan keluar site dibedakan untuk menghindari kemacetan. Selain sirkulasi untuk kendaraan bermotor disediakan sirkulasi pejalan kaki. Pada jalur pejalan kaki di beri trotoar dan pemanfaatan vegetasi berupa penanaman pohon guna kenyamanan pejalan kaki.

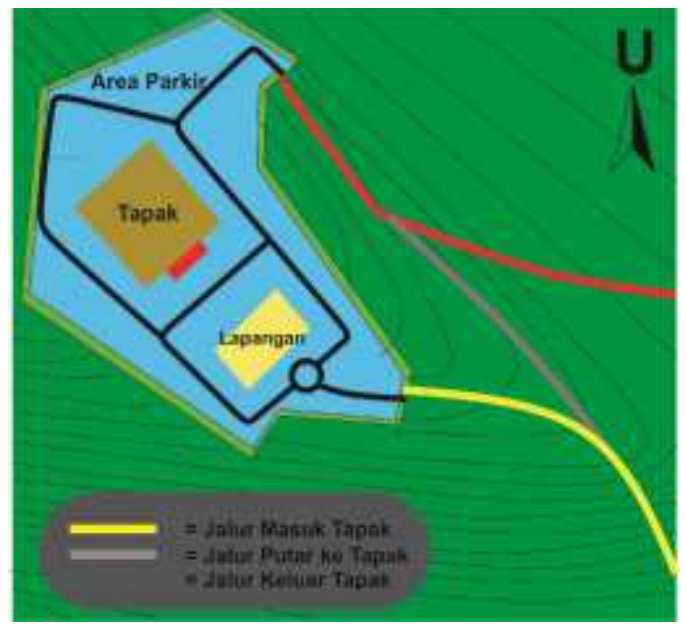

Gambar 2. Sirkulasi Pada Tapak

Sumber : Badan perencana pembangunan daerah, 2015

\subsubsection{Kebisingan}

Kebisingan adalah hal yang paling penting yang harus dihindari dari gedung perkantoran terutama pada Kantor bupati, Untuk meminimalisir kabisingan yang ada pada kawasan pemerintah maka diperlukan dengan meletakkan vegetasi disekitar tapak yang langsung berhubugan dengan sumber bising, diharapkan dapat memfilter suara bising dari jalan raya. Atau menggunakan ruang-ruang penyangga pada daerah sumber bising seperti ruang public atau service yang tidak memerlukan ketenangan.

Dari pola jalan yang sudah ada dan analisis site dan tapak sebelumnya, dapat diketahui bahwa tingkat kebisingan pada site tidaklah begitu besar karena terletak pada kawasan perbukitan dan masih banyak pohon-pohon yang mengurangi kebisingan. 


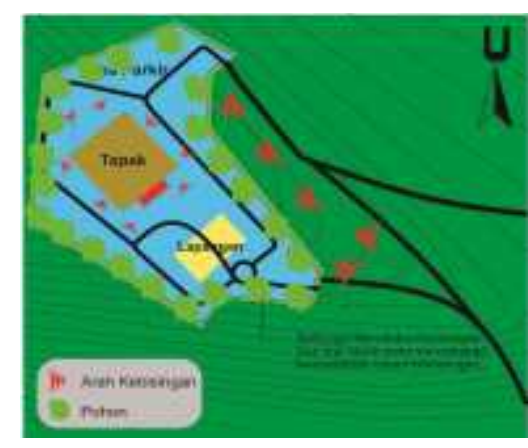

Gambar 3. Tingkat kebisingan tapak Sumber : Badan perencana pembangunan daearah, 2015

\subsubsection{Orientasi matahari}

Sinar matahari selain memberikan pencahayaan alami yang berguna untuk penerangan ruangan, juga dapat menimbulkan panas akibat radiasi yang ditimbulkannya. Orientasi bangunan yang terbaik ditinjau dari arah sinar matahati adalah dengan meletakkan bangunan terpanjang sejajar dengan arah matahari (Timur-Barat). Apabila tidak memungkinkan proses pembentukan atap bangunan bermassa yang terjadi, untuk menghindari sinar matahari langsung, dapat dicapai dengan penggunaan sunscreen dan pohon-pohon sebagai filterisasi sinar matahari secara langsung dan sebagainya.

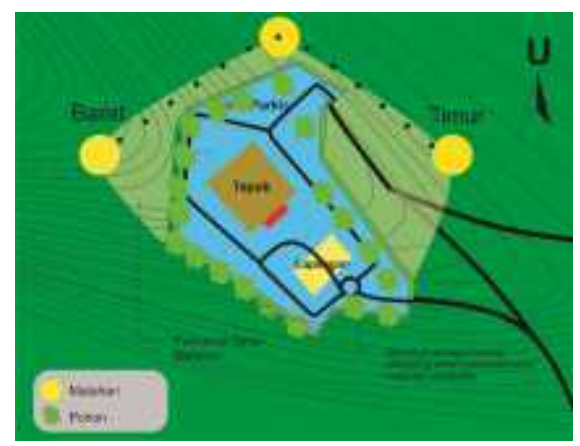

Gambar 4. Orientasi matahari pada tapak Sumber : Badan perencana pembangunan daearah, 2015

\subsubsection{Sistem utilitas}

Pada umumnya sistem utilitas berupa listrik, air bersih, dan telepon telah tersedia pada tapak. Namun untuk akses jalan belum di aspal hal ini di karenakan karna pengerjaan jalan yang masih dalam tahap pengerjaan. Jadi hanya penyaluran utilitas ke lokasi yang dibutuhkan.

\subsubsection{Curah Hujan}

Pada umumnya curah hujan di kolaka timur termasuk wilayah dengan curah hujan sedang yakni 20-50 $\mathrm{mm} /$ hari atau $5-10 \mathrm{~mm} / \mathrm{jam}$. Apabila di rataratakan perbulan yakni $1788.70 \mathrm{~mm}$ pertahun. Jadi untuk pembangunan kantor bupati cukup baik dengan curah hujan yang sedang. Memngingat kawasan kantor bupati berada pada pada daerah ketinggian.

\subsubsection{Orientasi Terhadap Angin}

Arah angin yang bertiup dari arah barat teluk bone mempengaruhi iklim di Sulawesi tenggara khususnya di kolaka timur. Dapat dilihat pada gambar berikut

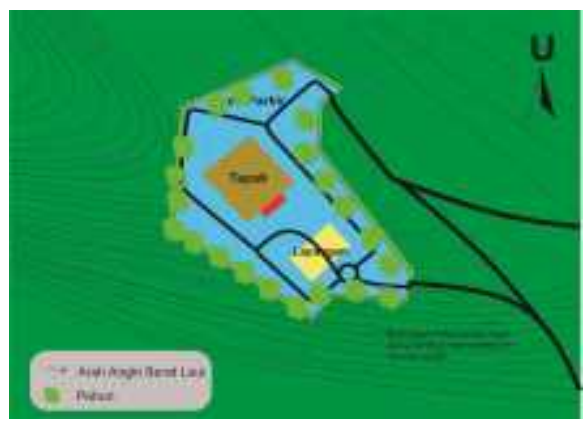

Gambar 5. Orientasi terhadap angin (Sumber : Bapeda)

Angin laut yang berhembus atau berasal dari sebelah barat site menmberikan penghawaan alami pada gedung, dengan memberikan bukaan-bukaan yang lebih banyak atau lebih besar pada bagian barat gedung. Selain udara sejuk yang diberikan oleh angin laut sebagai efek positif terhadap gedung. Hal ini tidak memberikan efek negatif pada gedung karna geografis terletak pada bagian barat Propinsi Sulawesi Tenggara memanjang dari utara ke selatan berada diantara 2o00' - 5o00' Lintang Selatan dan membentang dari barat ke timur diantara 120o45' 124o06' Bujur Timur.

\subsubsection{Analisa Lingkungan Sekitar}

Keadaan lingkungan di sekitar site pada kawasan pemerintahan ini sebagian sudah dibangun perkantoran dan sebagiannya masih dalam proses perencanaan pembangunannya sebagai bangunan pemerintah daerah kabupaten Kolaka Timur, Seperti terlihat pada gambar di bawah ini.

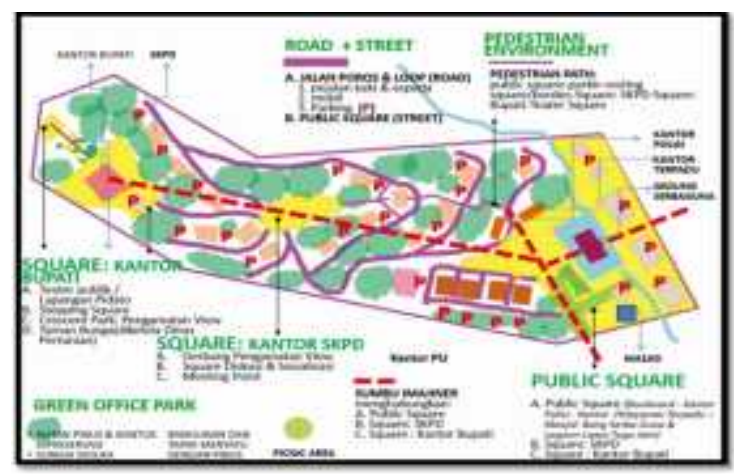

Gambar 6. Anlisa lingkungan sekitar Sumber : Bapeda 


\subsection{Pendekatan Mikro}

\subsubsection{Kebutuhan ruang}

Analisis penentuan kebutuhan ruang dilakukan berdasarkan aspek pelaku dan jenis kegiatan pada Kantor Bupati.

1) Identifikasi Pelaku Kegiatan

a) Pegawai

Pegawai terdiri dari kelompok utama ( Bupati, wakil bupati, Sekertaris daerah, Asisten I, Asisten II, Asisten III, Kabag, dan subag). Kelompok pengelola/karyawan dan pengguna fasilitas umum di Kantor Bupati

b) Pengunjung

- Pengunjung perorangan, melakukan kunjungan atau pertemuan di Kantor Bupati

- Pengunjung berkelompok, melakukan pertemuan seluruh pegawai.

2) Identiikasi jenis kegiatan

Secara umum jenis kegiatan yang dilakukan pada Kantor Bupati adalah sebagai berikut :

a) Kegiatan kelompok utama

Kegiatan melaksanakan tugas (kerja), mengadakan rapat besar, rapat intern, membuat laporan kegiatan, laporah harian, diskusi, bersosialisasi, melakukan pertemuan kepada seluruh pegawai, dan evaluasi pekerjaan

b) Kegiatan pengelolaan

Pada kegiatan pengelolaan terdapat jenisjenis kegiatan :

- Bagian administrasi yang menerima dan melayani pengunjung dengan memberikan informasi tentang kegiatan Kantor Bupati yang ada. Mengurus administrasi dan keuangan serta mengontrol penggunaan fasilitas yang ada

- Service/pelayanan. Adalah bagian yang memberikan pelayanan terhadap pengunjung berupa fasilitas pertemuan, rapat, keamanan, pelayanan parkir dan penjagaan kendaraan serta memberikan informasi kepada pengunjung jika ada sesuatu hal yang tidak diketahui.

\subsubsection{Perhitungan Besaran ruang}

Perhitungan besaran ruang dihitung berdasarkan pertimbangan:

- Jenis kegiatan (Kegiatan Pokok, kelompok fasilitas Umum, Kegiatan Penunjang dan Kegiatan Service)

- Kapasitas (jumlah pegawai) pelaku sampai tahun 2035 (230 pegawai)

- Jumlah dimensi perabot yang digunakan

- Standar yang digunakan, yaitu Standar prasarana kantor pemerintahan kepmen no.7 tahun 2006 dan Data arsitek
- Undang-Undang no. 73 tahun 2011

\subsubsection{Pendekatan Bentuk dan Tampilan}

1) Analisa bentuk

Analisa bentuk pada bangunan Kantor Bupati kolaka timur ini tidak lepas dari unsur-unsur budaya seperti yang telah di bahas pada bab sebelumnya. Bercerita tentang suku pada daerah Kolaka timur, Suku Tolaki dan suku Wolio merupakan dua suku yang sangat menonjol di pulau Sulawesi Tenggara yang menerapkan sistem nilai budaya ketika membangun suatu rumah untuk ditinggali ataupun rumah.

Dilihat secara horizontal bagian depan rumah berbentuk simetris, berkaitan dengan bentuk formil. Sedangkan asimetris terkait dengan dinamis. Makna tersebut terkait dengan sifat orang Tolaki yang dinamis dan formil. Tampak dari depan atau disebut fasad bagian bawah atau rangka dan lantai dianalogikan dengan dada dan perut manusia. Bagian loteng atau bagian atas dianalogikan punggung manusia sedangkan penyangga dianalogikan sebagai tulang punggung manusia. Sedangkan atap adalah rambut atau bulu. Bagian atap dianalogkan muka dan panggul manusia. Sebagaimana konsep bangunan pemerintahan yang banyak di terapkan pada bangunan pemerintah di sulawesi tenggara.

Bentuk dasar kotak, segitiga, persegi yang akan digabungkan dengan bentuk geometri dasar lainnya, seperti bentuk bujur sangkar, lingkaran, dan segi banyak yang akan diolah.

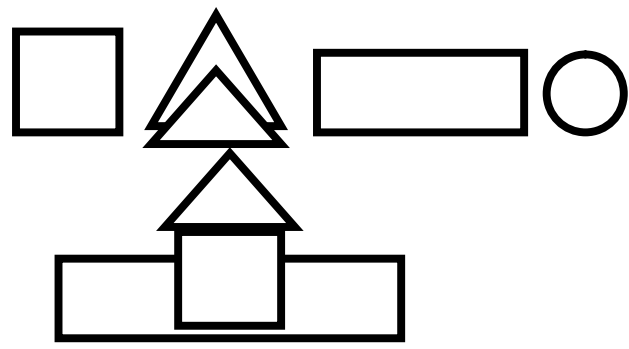

Gambar 7. Bentuk dasar Sumber: Studi pribadi

Bentuk dasar kotak, segitiga dan persegi panjang pada umumnya di gunakan pada semua bangunan baik itu bangunan tradisional ataupun bangunan moderen. pada bab sebelumnya bahawa bangunan pemerintah harus mempertimbangkan kaidah pelestarian bangunan baik dari segi sejarah meupun langgam arsitekturnya.

2) Analisa Tampilan

Dengan memperhatikan dari analisa tapak yang telah dijelaskan pada bab sebelumnya dan analisa bentuk, maka desain tampilan bangunan yang diharapkan adalah menjadi unite dengan desain bangunan pemerintahan 
yang sudah ada pada kawasan pemerintahan. Selain itu, desain tampilan bangunan diharapkan juga mampu beradaptasi dengan iklim dan kondisi site yang alami.

Karakteristik bangunan mencerminkan suatu fungsi dan kegiatan gedung Kantor Bupati Kolaka Timur dengan kegiatan utamanya yaitu sebagai pusat pemerintah. Yang menjadi fokus utama untuk tampilan dari Kantor Bupati Kolaka Timur ada pada bagian atap dan ukiran pada gedung, atap bangunan kantor bupati mengikuti bentuk atap bangunan adat Kolaka yakni Raha Bekeo yang merupakan rumah Raja mekongga kolaka yang dimodifikasi atau di sesuaikan dengan kondisi arsitektur yang berkembang pada saat ini. Atap bangunan adat Raha Bekeo yang berbentuk segi tiga Seperti terlihat pada gambar di bawah ini :

\subsubsection{Tata Ruang Dalam}

Pola sirkulasi ruang dalam memakai pola radial agar tidak menyulitkan pengguna mencapai ruangruang yang akan dituju. Pola radial ini memadukan unsur sirkulasi terpusat dan linier. Area di pusat adalah yang menjadi pusat sirkulasi berupa hall atau lobby sehingga memudahkan pengguna untuk mencapai ruang-ruang linier yang berkembang pada jari-jarinya.

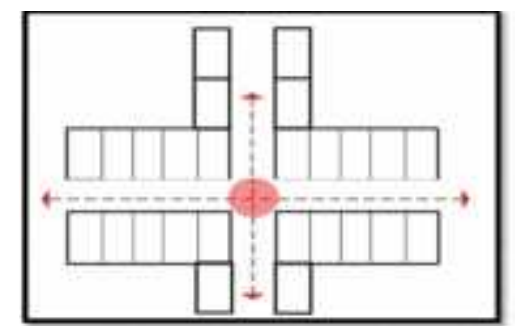

Gambar 8. Pola Sirkulasi Radial

Sumber : dok Penulis

Pendekatan tata ruang dalam sebagai salah satu cara untuk mendukung aktifitas dalam ruang sesuai dengan fungsi bangunan sehingga ada beberapa yang menjadi dasar pertimbangan yaitu :

- Fungsi bangunan

- Kenyamanan

- Keseimbangan

Material yang digunakan pada bidang dinding, lantai dan plafond. Adapun elemen yang perlu diperhatikan dalam penataan ruang dalam adalah sebagai berikut:

1) Dinding

Dinding adalah bagian dari bangunan yang berfungsi sebagai pemisah antara ruangan luar dengan ruangan dalam, melindungi terhadap intrusi dan cuaca, penyokong atap dan sebagai pembatas ruang satu dengan ruangan lainnya.Ditinjau dari segi material yang digunakan, dinding dapat dibedakan menjadi : a) Dinding batu bata

Batu bata merupakan salah satu bahan material sebagai bahan pembuat dinding. Umumnya memiliki ukuran: panjang $17-23 \mathrm{~cm}$, lebar $7-11 \mathrm{~cm}$, tebal $3-5 \mathrm{~cm}$. Berat rata-rata 3 $\mathrm{kg} / \mathrm{biji}$.

Adapun kelebihan dinding bata merah adalah kedap air, sehingga jarang terjadi rembesan pada tembol akibat air hujan, keretakan relatif jarang terjadi, kuat dan tahan lama, memberikan suhu yang tepat pada ruangan (terlebih pada iklim tropis). Pada cuaca panas, material bata merah akan mereduksi panas sehingga suhu ruangan lebih sejuk. Pada saat angin atau hujan, dinding bata tidak terlalu berpengaruh pada suhu ruang.Adapun kekurangan dinding bata merah adalahwaktu pemasangan lebih lama dibandingkan batako dan bahan dinding lainnya, dan biaya lebih tinggi.

b) Beton Ringan

Salah satu produk beton ringan CLC adalah bata ringan CLC yang saat ini sudah banyak dikenal teknologi AAC merupakan pembuatan batu bata ringan.

c) Dinding kaca

Dinding kaca adalah serangkaian panel kaca individu yang tetap dalam kusen aluminium atau bingkai kayu. Kelebihan dari dinding kaca yaitu memberikan efek serupa cermin. Fungsinya bukan untuk memantulkan bayangan ruang, namun memberikan kesan luas pada ruang.Selain itu, kaca juga memungkinkan banyak cahaya alam masuk menerangi ruang di dalam rumah sehingga pada siang hari misalnya, tidak diperlukan lampu pada ruang-ruang yang berbatasan langsung dengan ruang luar. Sebaiknya hindari memasang kaca dalam ukuran besar pada dinding bangunan sebelah timur, terlebih lagi sebelah barat.. Idealnya, dinding kaca ditempatkan pada area bangunan yang menghadap ke utara atau selatan.

d) Dinding partisi

Sesuai dengan namanya dinding partisi memang dikhususkan untuk sekat antar ruang. Karena di desain sebagai sekat antara ruang satu dan yang lain, dinding ini memiliki desain konstruksi yang lebih praktis dan ringan dibanding dengan konstruksi dinding yang lain. Bahan yang dipakai umumnya terdiri dari lembaran multiplek atau papan gipsum dengan ketebalan 9-12 mm. pemasangan kerangka (kayu atau hollow) menggunakan sekrup. Bahannya mudah dipotong hanya menggunakan gergaji. Ketebalannya beragam mulai dari $4 \mathrm{~mm}, 6 \mathrm{~mm}, 9$ $\mathrm{mm}, 12 \mathrm{~mm}$, dan $15 \mathrm{~mm}$. Panjang dan lebarnya sama dengan ukuran lembaran tripleks, yaitu 122 $\mathrm{cm} \times 244 \mathrm{~cm}$.

e) Lantai

Lantai merupakan penutup permukaan tanah dalam ruangan dan sekitarnya. Lantai juga 
bagian bangunan yang digunakan untuk pijakan kaki. Adapun jenis lantai yang rencana akan digunakan adalah :

(1) Lantai keramik, digunakan pada ruangruang semi service seperti dapur, toilet, gudang. Lantai jenis ini memiliki ukuran yang seragam, yaitu $20 \times 20 \mathrm{~cm}$, $30 \times 30 \mathrm{~cm}, 40 \times 40 \mathrm{~cm}, 10 \times 10 \mathrm{~cm}$, dan $10 \times 20 \mathrm{~cm}$. Adapun ketebalan pada lantai ini pada umumnya $10 \mathrm{~mm}$.

(2) Keramik yang berteksur kasar cocok digunakan untuk lantai yang sering terkena air agar tidak licin, sedangkan keramik yang bertekstur lebih halus cocok digunakan di dalam ruangan.

(3) Lantai marmer, digunakan pada ruangan yang sifatnya privat dan service. Material marmer memiliki kesan dingin dan kuat. Kelemahan marmer adalah memiliki pori-pori relatif besar sehingga membutuhkan perawatan ekstra. Adapun ukuran lantai marmer yaitu5 $\mathrm{x}$ $20 \mathrm{~cm}, 10 \times 20 \mathrm{~cm}, 15 \times 30 \mathrm{~cm}, 20 \times 20$ $\mathrm{cm}, 50 \times 50 \mathrm{~cm}$, dll.

(4) Lantai granit, digunakan pada ruangan yang sifatnya public seperti lobby, entrance, dan. Granit memiliki pori-pori yang lebih rapat, sehingga memiliki kemungkinan yang lebih kecil untuk dimasuki air dan kotoran. Adapun ukuran lantai granit adalah30 x $30 \mathrm{~cm}$, f) Plafond $40 \times 40 \mathrm{~cm}, 60 \times 60 \mathrm{~cm}$, dll

Plafon adalah bagian dari konstruksi bangunan yang berfungsi sebagai langit-langit bangunan.Plafon dibuat dengan maksud untuk mencegah cuaca panas atau dingin dan juga sebagai hiasan yang akan lebih mempercantik interior suatu bangunan.

Ukuran untuk plafon adalah $122 \mathrm{~cm}$ x 244 $\mathrm{cm}$ dengan ketebalan $6 \mathrm{~mm}, 9 \mathrm{~mm}, 12 \mathrm{~mm}$. Untuk rangka seperti GRC Board dapat menggunakan kasau maupun besi hollow.Keunggulan, pada saat terpasang plafon gypsum memiliki permukaan yang terlihat tanpa sambungan sehingga banyak diminati masyarakat. Proses pengerjaanya pun lebih cepat. Mudah diperoleh, diperbaiki serta diganti.

b) Tata Ruang Luar

Pendekatan penataan ruang luar untuk gedung Kantor Bupati sangatla penting dikarnakan untuk area ruang luar pada kantor bupati selain sebagai area parkir taman dan lapangan upacara oleh karna itu pemanfaatannya ditata secara optimal. Dimana antara area tidak mengganggu aktifitas di area lain. Selain itu, elemen-elemennya juga berfungsi untuk mendukung terciptanya penghawaan yang segar dan pencahayaan yang baik bagi bangunan. Dalam perencanaan ruang luar dikenal dua bagian besar elemen, yakni material lunak (soft materials) dan material keras (hard materials).

\subsubsection{Hard Material (Elemen Keras)}

Elemen keras pada area parkir menggunakan grass block dan paving block. Sedangkan pada jalur sirkulasi yang tertutup atap dapat memakai keramik seperti lantai ruang dalam atau kayu, dan pada jalur sirkulasi yang tidak beratap dapat menggunakan semen bertekstur.
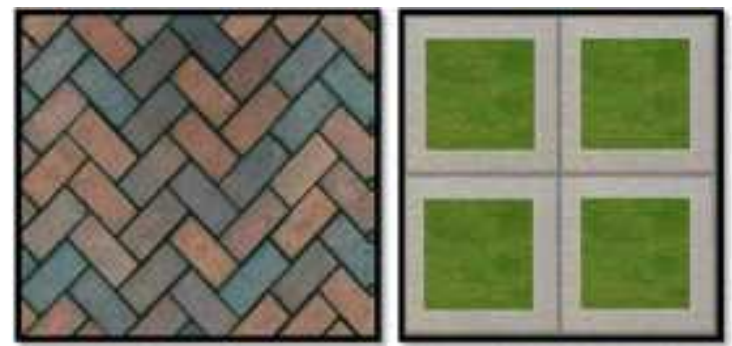

Gambar 9. Elemen Penutup Tanah Pada Lansekap Luar

Sumber: Analisis, 2014

\subsubsection{Soft Material (Elemen Lunak)}

Vegetasi merupakan elemen luar bangunan yang memiliki berbagai fungsi. Adapun fungsi-fungsi tersebut antara lain:

(1) Sebagai barrier terhadap kebisingan maupun polusi

(2) Sebagai peneduh

(3) Elemen estetika landscape bangunan.

(4) Pembentuk batas ruang

(5) Pengendali kecepatan angin

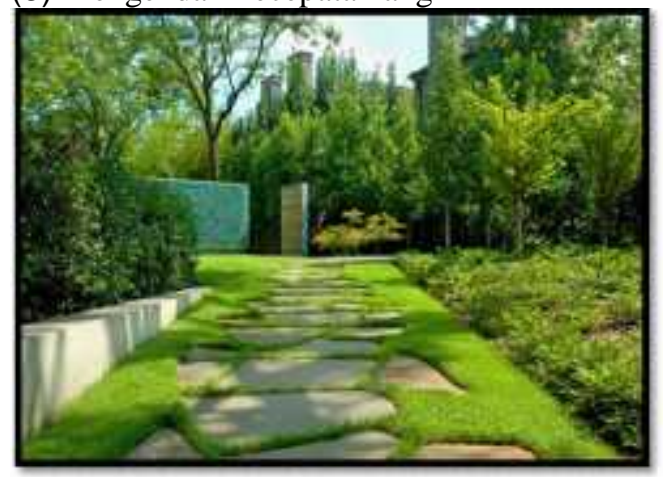

Gambar 10. Contoh : Elemen vegetasi pada ruang luar bangunan Sumber: Analisis, 2014

\subsubsection{Struktur dan Material}

Pemilihan sistem struktur yang sesuai untuk Kantor Bupati di Kabupaten Kolaka Timur dengan mempertimbangkan hal-hal sebagai berikut :

1) Kekuatan dalam menerima beban.

2) Tidak mengganggu aktivitas yang terjadi dalam ruangan.

3) Efesiensi dan fleksibilitas pengembangan.

4) Ekomonis dalam biaya dan waktu pemeliharaan. 


\subsubsection{Sistem Utilitas Bangunan}

a) Sistem jaringan listrik

Aliran listrik berasal dari dua sumber yaitu dari PLN dan dari genset. Listrik dari PLN digunakan sebagai sumber tenaga listrik utama, sedangkan aliran listrik dari genset sebagai sumber tenaga listrik cadangan yang berfungsi otomatis ketika tenaga listrik PLN terputus.

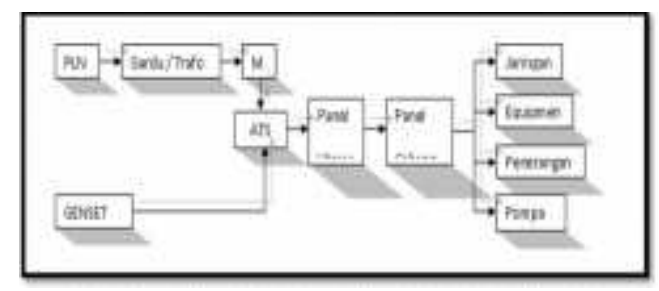

Gambar IV.25. Sistem Jaringan Listrik (Sumber :Analisa penulis)

b) Sistem jaringan air bersih

Air bersih berasal dari 2 sumber yaitu dari PDAM dan sumber air tanah (air artesis). Proses distribusi air bersih dari PDAM ditampung lebih dahulu dalam reservoir bawah kemudian dipompa ke reservoir atas dan didistribusikan ke bangunan. Untuk mengantisipasi kurangnya persediaan air bersih karna macetnya air PDAM maka digunakan air tanah (air artesis).

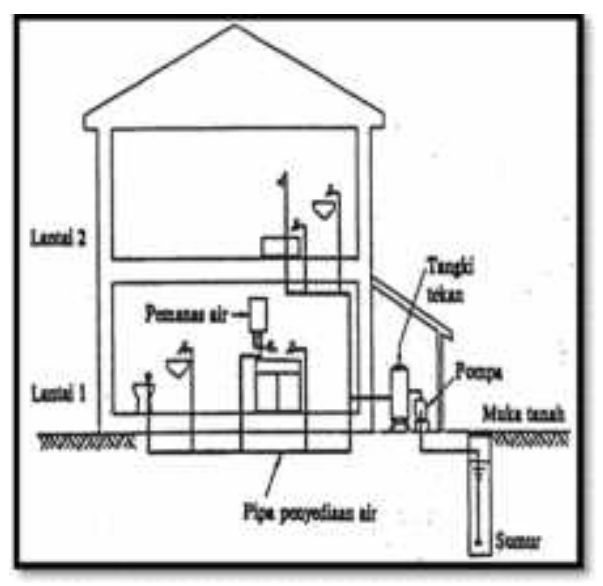

Gambar IV.26. Sistem Jaringan Air Bersih (Sumber : Analisa penulis)

c) Sistem pembuangan air kotor

(1) Disposial padat

Disposial padat yang berasal dari WC disalurkan ke septictank dan bak peresapan melalui pipa yang ditanam dalam tanah.

(2) Air kotor

Air kotor yang berasal dari kamar mandi, wastafel, dapur, urinoir serta air hujan disalurkan melalui bak kontrol dan kemudian disalurkan ke pembuangan kota.

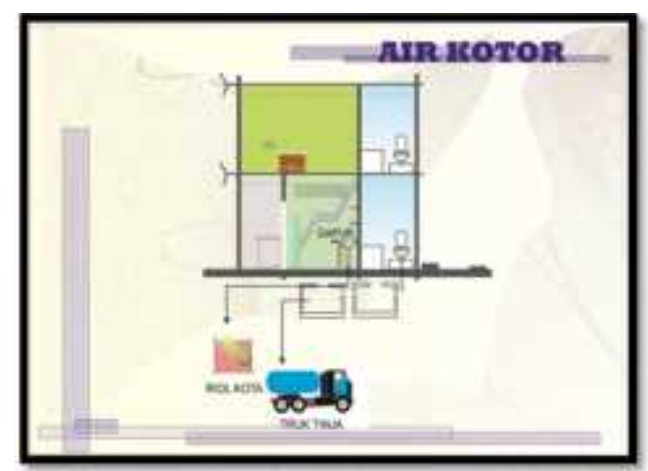

Gambar IV.27. Sistem pembuangan air kotor (Sumber : Analisa penulis)

d) Sistem pembuangan sampah

Sampah adalah suatu bahan yang terbuang atau dibuang dari sumber hasil aktifitas manusia. Jenis sampah terbagi menjadi dua yaitu sampah basah dan sampah kering. Sampah basah yaitu sisa pembuangan sampah cair seperti sisa-sisa makanan. Adapun sampah keringadalah kertaskertas, kaleng-kaleng, puntung rokok, plastik dan potongan logam.

Sistem pembuangan sampah basah dan kering yang telah dihasilkan, dikumpulkan pada bak sampah yang telah disiapkan dan kemudian diangkut oleh Dinas Kebersihan Kota ke Tempat Pembuangan Akhir (TPA).

e) Sistem komunikasi

Sistem komunikasi yang biasa digunakan terdiri dari dua yaitu: komunikasi internal dan komunikasi eksternal

(1) Komunikasi internal

Komunikasi internal Adalah segenap kegiatan komunikasi yang secara khusus diarahkan pada pihak-pihak di lingkungan bangunan. Yang terdiri dari :

- Interkom, untuk komunikasi dua arah antar ruangan dalam gedung

- Sound sistem, untuk komunikasi satu arah yaitu memberikan informasi atau panggilan di dalam gedung

- Dan walkie talkie, untuk kooordinasi pelayanan di luar gedung.

(2) Komunikasi eksternal

Adalah segenap kegiatan komunikasi yang diarahkan pada pihak-pihak di luar bangunan. Yang terdiri dari :

- Telepon, untuk komunikasi dua arah baik ke dalam maupun ke luar gedung dengan menggunakan jasa PT. Telkom.

- Faksimile, untuk komunikasi dan mengcopy dokumen yang diinginkan.

- PABX (Privat Automatic Branch Exchange), untuk hubungan langsung ke luar masuk gedung bangunan melalui operator. 


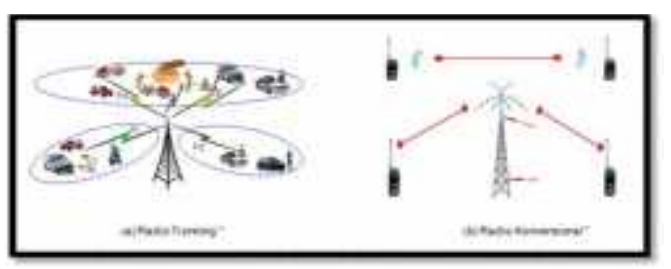

Gambar 30. Sistem komunikasi eksternal

(Sumber : https://www.google.co.id. utilitas.komunikasibangunan)

f) Sistem penanggulangan kebakaran

Untuk mengantisipasi kebakaran yang telah terjadi agar tidak meluas, digunakan alat kebakaran seperti tabung Co2diletakkan pada tempat-tempat yang mudah dijangkau. Fire hydrant diletakkan di luar bangunan (tempat terbuka) di bagian-bagian yang strategis. Selain itu penyediaan sprinkler pada tiap-tiap ruangan.

g) Sistem penangkal petir

(1) Sistem franklin

Sebuah batang yang runcing dari bahan cooper spit yang dipasang pada paling atas bangunan, dan dihubungkan dengan batang tembaga menuju elektroda tanah (mencapai permukaan air ). Daerah yang dilindungi dari sambaran petir berbentuk segitiga kerucut dengan ujung penyalur petir pada puncaknya. Disistem ini hanya menggunakan sebuah spit penangkal petir yang dipasang pada tempat tertinggi.

(2) Sistem sangkar faraday

Pada prinsipnya seperti franklin tetapi dibuat memanjang atau berbentuk sangkar sehingga jangkauan lebih luas. Sistem ini dipakai pada bangunan yang punya atap yang luas. Dalam satu bangunan menggunakan lebih dari 4 spit sebagai penangkal petir.

\subsubsection{Pendekatan sistem pengkondisian ruang}

a) Sistem pencahayaan

Pencahayaan merupakan salah satu faktor untuk mendapatkan keadaan lingkungan yangaman dan nyaman dan berkaitan erat dengan produktivitas manusia. Pencahayaan yang baikmemungkinkan orang dapat melihat objekobjek yang dikerjakannya secara jelas dan cepat. Menurut sumbernya, pencahayaan dapat dibagi menjadi :

1) Pencahayaan alami

Pencahayaan alami adalah sumber pencahayaan yang berasal dari sinar matahari. Untuk mendapatkan pencahayaan alami pada suatu ruang diperlukanjendela-jendela yang besar ataupun dinding kaca sekurang-kurangnya 1/6 daripada luas lantai.

Faktor-faktor yang perlu diperhatikan aga penggunaan sinar alami mendapat keuntungan, yaitu:

- Variasi intensitas cahaya matahari

- Distribusi dari terangnya cahaya
- Efek dari lokasi, pemantulan cahaya, jarak antar bangunan

- Letak geografis dan kegunaan bangunan gedung.

2) Pencahayaan buatan

Pencahayaan buatan adalah pencahayaan yang dihasilkan oleh sumber cahaya selain cahaya alami, secara umum cahaya tersebut berasal dari hasil karya manusia berupa lampu yang yang berfungsi menyinari ruangan sebagai pengganti jika sinar matahar tidak ada. Sistem pencahayaan buatan yang sering dipergunakan secara umum dapat dibedakan atas 3 macam yakni:

- Sistem pencahayaan merata

Pada sistem ini iluminasi cahaya tersebar secara merata di seluruh ruangan. Sistem pencahayaan ini cocok untuk ruangan yang tidak dipergunakan untuk melakukan tugas visual khusus.

- Sistem pencahayaan terarah

Pada sistem ini seluruh ruangan memperoleh pencahayaan dari salah satu arah tertentu. Sistem ini cocok untuk pameran atau penonjolan suatu objek karena akan tampak lebih jelas.

- Sistem pencahayaan setempat

Pada sistem ini cahaya dikonsentrasikan pada suatu objek tertentu misalnya tempat kerja yang memerlukan tugas visual.

b) Sistem penghawaan

Adalah suatu usaha pembaharuan udara dalam ruang melalui penghawaan buatan maupun penghawaan alami dengan pengaturan sebaikbaiknya dengan harapan untuk mencapai tujuan kesehatan dan kenyamanan dalam ruang.

\section{1) Penghawaan alami}

Penghawaan alami adalah proses pertukaran udara di dalam bangunan melalui bantuan elemen-elemen bangunan yang terbuka. Yang perlu diperhatkan dalam pemanfaatan penghawaan alami yaitu

- Aliran dan pengendapan udara diusahakan untuk selalu terjadi ventilasi silang atau cross ventilation sehingga udara dalam ruangan terus mengalir dan tetap sehat.

- Kondisi lingkungan bangunan agar polusi dan debu dapat dihilangkan atau disaring dengan menggunakan vegetasi.

2) Penghawaan buatan

Penghawaan buatan dapat diaplikasikan dengan menggunakan AirConditioning, kipas, dan exhaust fan.

- Air Conditioning

Terdiri dari dua sistem yaitu AC Central

/ Central Station System. Sistem AC ini 
biasa digunakan pada ruang seperti kantor pengelola, hall/lobby, kafetaria. Dan AC Unitary Systemyang kapasitasnya secukupnya, pengoperasiannya yang relatif mudah seperti ruang rapat, dan sebagainya.

- Kipas angin

Kipas angin dipergunakan untuk menghasilkan angin. Fungsi yang umum adalah untuk pendingin udara, dan penyegar udara.

- Exhaust fan

Exhaust fan berfungsi untuk menghisap udara di dalam ruang untuk dibuang ke luar, dan pada saat bersamaan menarik udara segar di luar ke dalam ruangan. Selain itu exhaust fan juga bisa mengatur volume udara yang akan disirkulasikan pada ruang agar udara tetap segar dan sehat.

\subsection{Hasil}

a) Lokasi dan site yang dipilih dalam merencanakan kantor bupati di Kabupaten Kolaka timur merupakan lokasi yang strategis berada di kawasan perkantoran, pencapaian yang mudah dari segala arah kawasan perkantoran dan berada di kawasan perbukitan sehingga bangunan dapat dilihat dari dataran rendah dan terhindar dari kebisingan.

b) Bentuk penampilan bangunan Kantor bupati di Kabupaten Kolaka timur disesuaikan dengan bangunan melalui pertimbangan penerapan arsitektur untuk sebuah bangunan pemerintah seperti pemberian karakteristik budaya local pada bangunan, sehingga penerapan dan simbol budaya local tetap terjaga meskipun unsur-unsur material dan desain bangunan sudah moderen.

\section{KESIMPULAN}

Kantor Bupati di Kolaka Timur merupakan salah satu wadah pemerintahan yang bertujuan mnampung kegiatan sekertariatan daerah dan memfasilitasi serta mendukung kebijakan pembangunan dan pelayanan terhadap masyarakat yang ada di kabupaten Kolaka Timur.

Selain itu kantor bupati merupakan bagian dari simbol kebanggaan daerah baik itu dari segi administras maupun dari segi konsep bangunan. Maka dari itu, lokasi penentuan letak bangunan, kondisi tapak, aksesbilitas dan memberikan sebuah ciri khas budaya local sangatlah penting dalam pembangunan gedung kantor bupati.

\section{DAFTAR PUSTAKA}

- Administrasi Umum. 2016. (Sumber: http://sekda baubaukota.go.id).
- Alternatif Penentuan Site Kecamatan Tirawuta (Sumber: Google Earth).

- Analisa lingkungan sekitar (Sumber : Bapeda).

- Analisa Zoning (Sumber : Bapeda).

- Area Parkir Kantor Bupati Kolaka Timur (Sumber : Foto Pribadi).

- Bagian Organisasi dan Tata Laksana sekertariat Daerah, 2015. Kolaka Timur.

- Bentuk Fisik Kantor Bupati Kolaka Timur (Sumber : Foto Pribadi).

- Catatan Sipil dan Kependudukan, 2015. Kolaka Timur.

- Ekonomi dan Pembangunan. 2016 . ( Sumber :http://sekdabaubaukota.go.id).

- Exhaust Fan Sebagai Penghawaan Buatan (Sumber http://www.aryaniarts.com/2012/09/carapemasangan-exhaust-fan-yang-benar.html)

- Existing Condition Tapak (Sumber: Badan perencana pembangunan daearah dan foto pribadi 2015).

- Fasad Raha Bokeo , Raja Bokeo, kerajaan Mekongga di Kolaka suku Tolaki. (Sumber : www.studentjournal.petra.ac.id).

- Gedung Induk Puspem Badung, (Sumber : http://www.balipost.co.id).

- Kantor Bupati Deli serdang (Sumber: www.deliserdangkab.go.id).

- Kantor Bupati Kabupaten Lima Puluh Kota (Sumber: www.kompasiana.com).

- Kantor Bupati Kabupaten Kolaka Timur (Sumber :Foto Penulis).

- Kantor Bupati Buton (Sumber: http://www.indoplaces.com/Bangunan pemerintah sulawesi tenggara).

- Kantor Bupati Kolaka (Sumber: http://www. indoplaces.com/Bangunan pemerintah sulawesi tenggara).

- Neufert, Ernst. 1996.Data Arsitek Jild 1 Edisi 33. Erlangga. Jakarta.

- Neufert, Ernst. 1996.Data Arsitek Jild 2 Edisi 33. Erlangga. Jakarta.

- Orientasi matahari pada tapak (Sumber : Badan perencana pembangunan daearah, 2015).

- Ornament Raha Bokeo kerajaan Mekongga, suku Tolaki. (Sumber : www. student journal .petra.ac.id).

- Peraturan Menteri Dalam Negeri Republik Indonesia Nomor 73 Tahun 2011.

- Penghawaan Alami (Sumber : http : // www .scribd.com/doc/97170855/22/SistemPenghawaan).

- Peta Administrasi Kabupaten Kolaka Timur (Sumber : Badan Perencanaan Pembangunan Daerah Kolaka timur).

- Peta Kelurahan Laligato (Sumber: Badan Perencnaan Pembangunan Daerah). 
- Peta Rencana Struktur Ruang Ibu Kota Kabupaten Kolaka Timur (Sumber : Badan Perencanaan Pembangunan Daerah Kolaka timur).

- Prediksi Jumlah Pegawai 2035 (Sumber : Bagian Organisasi dan Tata Laksana Sekertaris Daerah Kolaka Timur 2013-2015).

- Rencana Struktur Ruang Kabupaten Kolaka Timur (Sumber: Badan Perencana Pembangunan Daerah dan Analisa Penulis).

- Rumah Kepala Distrik Lambandia di daerah Mekongga/Kolaka Tahun 1911. (Sumber : www.studentjournal.petra.ac.id).

- Sekertariat Daerah. 2016. (Sumber: http://sekda baubaukota.go.id).

- Sirkulasi Pada Tapak (Sumber : Badan perencana pembangunan daerah, 2015). 